\title{
Influence of the Green Leadership Toward Environmental Policies Support
}

\author{
Kardoyo KARDOYOํ, Muhammad FERIADY², Nina FARLIANA ${ }^{3}$, Ahmad NURKHIN ${ }^{4}$
}

Received: August 01, 2020 Revised: September 20, 2020 Accepted: October 05, 2020

\begin{abstract}
This paper aimed to study the role of green leadership toward environmental policies support in university. Furthermore, this study investigated the influence of green leadership toward environmental policies support and discussed the mediation effect of Green Self efficacy, Green Mindfulness, organization identity and environmental responsibility. The number of Population sample in this research was taken from 1,456 lecturers and staff of Universitas Negeri Semarang, Indonesia. Total sample in this research is 312 respondents. Structural Equation Models (SEM) was used in this research to develop the model of green leadership role toward environmental policies support of Lecturer and Staff in the University. This study found that green leadership had significant influences toward environmental policies support, environmental responsibility, green mindfulness and green self-efficacy but had insignificant influence toward organizational identity. Path analysis showed strong mediation effect of environmental responsibility and green mindfulness, but had a weak mediation from organizational identity and green self-efficacy. Finally, this study concluded that the role of green leadership in influencing environmental responsibility and green mindfulness was required to be enhanced in order to increase the support of environmental policies at the university. Further study needs to be carried out to determine the effect of green leadership on green performance and green behavior in organizations.
\end{abstract}

Keywords: Green Leadership, Environmental Policy, Green Mindfulness, Organization Identity, Environmental Responsibility

JEL Clasification Code: M12, M54, I23

\section{Introduction}

In the last decade, research related to environmental policy has indeed becoming an interesting subject. Research on environmental policies has also developed into specific studies such as carbon emission (He, et.al, 2019; Arias \& Lucendo, 2019), green behavior (Nguyen, Nguyen \& Hoang, 2019), green management system (Kim, et.al, 2019) and many others. Research around environmental policies in universities in social studies still focuses on environmentally

${ }^{1}$ First Author and Corresponding Author. Lecturer, Faculty of Economics, Universitas Negeri Semarang, Indonesia [Postal Address: L2 Building, Sekaran Campus, Gunung Pati, Semarang, Central Java, 50229, Indonesia] Email: kardoyo@mail.unnes.ac.id ${ }^{2}$ Lecturer, Faculty of Economics, Universitas Negeri Semarang, Indonesia. Email: mferiady@mail.unnes.ac.id

${ }^{3}$ Lecturer, Faculty of Economics, Universitas Negeri Semarang, Indonesia. Email: farliananina@mail.unnes.ac.id

${ }^{4}$ Lecturer, Faculty of Economics, Universitas Negeri Semarang, Indonesia. Email: ahmadnurkhin@mail.unnes.ac.id

(c) Copyright: The Author(s)

This is an Open Access article distributed under the terms of the Creative Commons Attribution Non-Commercial License (https://creativecommons.org/licenses/by-nc/4.0/) which permits unrestricted non-commercial use, distribution, and reproduction in any medium, provided the original work is properly cited. oriented management and leadership (Al-Zawahreh, Khasawneh \& Al-Jaradat, 2019; Hamidi, Jufri \& Karta, 2019) this is inseparable from the importance of leadership in managing higher education. Unfortunately, there is still little research related to environmental policies that focusses on the concern of the academic community, towards the environmental policy at the university. Meanwhile research on a sustainable environment now has become the most important focus for life (Cosby, 2014).

The environmental issues in universities are important things to discuss. This is related to the role of the university as an educational institution which contributes to community development. Boca and Saraçlı (2019) stated that environmental education is very important and supports the creation of a sustainable environment. Based on this statement, it is interesting to study as to how the campus creates a green environment and supports sustainability?

The definition of green leadership can be seen from the environmental policies made by the leader (Boiral, Baron \& Gunnlaugson, 2014; Boiral, Raineri \& Talbot, 2018), but apart from this, leadership is also related to the ability of a leader to influence his members (Mittal \& Dhar, 2015). This means that green leadership not only refers to proenvironment policies, but also is reflected in the behavior 
of members of the organization towards pro-environmental policies. A good leader should be able to mobilize member participation in pro-environmental policies.

The existence of green leadership is very important in creating a sustainable environment (Malik, Saleem \& Naeem, 2015; Ali, 2019; Mittal \& Dhar, 2015). The role of green leadership is reflected in green policies that are implemented and can be supported by members of the organization. Norton, et.al. (2017); Lamm, et.al. (2016); Robertson and Barling (2015); Ones and Dilchert (2012) explained the relationship between leadership and green behavior of employees, including support for environmental policy and eco-friendly behavior. Malik, Saleem and Naeem (2015) explained the relationship between leadership and green behavior of employees by placing several psychological variables as mediators and moderators. Furthermore Kuenzi (2009) considered that leadership is a very good antecedent in influencing the behavior of employees.

Discussion of the relationship between leadership and perceptions of pro-environmental policy by its members can be explained through the Leader - Member - Exchange (LMX) theory proposed by Dansereau, Graen \& Haga (1975). This theory explains the existence of a close relationship between the actions of members of an organization which is based on the actions of leaders with the mechanism of exchange. Northouse (2018) explained that in LMX subordinates receive more information, trust, influence and role within the same work unit compared to outside groups. This pattern strongly emphasizes the good relations between leaders and their members (Yukl, 2015).

In contrast, social identity theory in leadership explains the opposite. This theory places social identity as a major factor influencing the behavior of organizational members (Hogg, et al., 2005). This can be used as an affirmation that good leadership is also supported by the social identity of good members as well. In relation to environmental performance, leadership needs to be oriented to the leader member exchange (LMX) model, where the exchange of information and influence between leaders and members is required to achieve the goal of a green environment.

Some previous studies have put the leadership style in a transformative and ethical manner that can improve members' environmental performance (Mittal \& Dhar, 2015; Malik, Saleem \& Naeem, 2015; Chen, et. al., 2014). Furthermore, studies on green leadership have only focused on definitions and outcomes in the form of pro-environmental policies. In some studies which is, related to leadership, it has always been associated with the categories of leadership styles and leadership structures (Graen \& Uhl-Bien, 1995). This research will describe the role of green leadership in increasing members' perceptions of pro-environmental policies. This relates to the existence of LMX values which naturally influences members' perceptions of policies made by the leadership (Yulk, 2015).
The discussion of these two theories is considered important, considering the fact that the leadership style possessed by leaders in organizations is very important toward organizational success (Yukl, 2015). This article will try to include several variables related to leader member exchanges, namely green leadership which is also related to the social identity theory related to organization identity.

Investigation of the influence of green leadership on the perception of pro-environmental policies in this study needs to bring up some mediating variables. Some previous research has linked mindfulness and self-efficacy as factors that mediate green leadership to green performance (Chen, et.al, 2014). This is also supported by the findings of Mahrani \& Soewarno (2018), who explain the mediating role of organizational identity towards green innovation.

Based on some previous research, no one has touched on the role of mindfulness, self-efficacy and organizational identity with the support of pro-environmental policies. This is then used as a research gap in this study. The development of green leadership relationship models in influencing organizational members to support pro-environmental policies can be analyzed by using the leadership exchange model (LMX) approach and social identity theory of leadership. The two theories of leadership contradict each other with regard to the role of leaders in the organization. Through the LMX model, we can know that good relations between leaders and members will greatly determine organizational performance. This shows that green leadership is considered successful when it is able to increase the support of organizational members for pro-environmental policies.

The attention and trust of organizational members in this study was measured by green self-efficacy and also green mindfulness. The social identity theory of leadership in this research shows that there are external factors outside the leadership that influences support for pro-environmental policies. In this theory it is explained that the existence of group dominance actually influences organizational decisions. In this regard, green organizational identity and environmental responsibility variables are used as variables that measure these external influences.

The research problems in this study are: first, all this time green leadership has been measured based on proenvironmental policies, but there has not been any studies on the role of green leadership in building the support of organizational members for environmental policies. Second, LMX theory which examines the relationship between leaders and members needs to be applied to investigate the phenomenon of green leadership. This relates to the flow of information relating to environmental policies and member support for those policies.

Third, there is a need for research that examines the mediating effects of self-efficacy, mindfulness, organizational identity and responsibility on the perception 
of pro-environmental policies. The aim of this research is to study the role of green leadership on environmentally friendly perceptions at universities. Furthermore, this study investigates the effect of green leadership on environmentally friendly perceptions and discusses the mediating effects of green self-efficacy, green mindfulness, organizational identity and environmental responsibility.

\section{Literature Review}

\subsection{Leader Member Exchange and Social Identity Theory}

A good relationship between leaders and subordinates can be shown from the existence of feelings of mutual trust, liking, respect and feelings of mutual need (Liden, Sparrowe \& Wayne, 1997). LMX theory as explained by Graen and Uhl-Bien (1995) is the behavior of members who are more receptive to information, influence and direction from their leaders compared to information and influence from outsiders. High-quality relationships between leaders and members are associated with several positive workrelated outcomes, namely, job satisfaction and organizational commitment (Martin et al, 2016). Study from TRAN, LEE, NGUYEN (2020) find that the LMX is related with behavior of organization members. It means that the members' support for pro-environmental policies is determined by the leadership relationship with the members based on the members' trust in their leaders.

Contrary to this, in the social identity of leadership model, the behavior of members is not solely determined by the relationship of members with their leaders, but also comes from external factors, namely the dominant group (Rast, Gaffney, Hogg \& Crisp, 2012). Rast, Gaffney, Hogg \& Crisp (2012) explained that in LMX model there could not be a good relationship between leaders and members of the organization due to the presence of a dominant group which determines the perceptions of leaders. In this regard it can be assumed that the pro-environmental policies made by the leadership are not necessarily supported by members of the organization.

\subsection{Green Leadership}

Integration model of organizational or institutional behavior according to Colquitt et.al (2011), namely the leader and employees as individuals can be assessed from individual achievements (job outcomes), namely job performance or behavior that gives good or bad contribution and organizational commitment (organizational performance). Green leadership can have an impact on relationships between individuals and organizations in an effort to achieve sustainable goals in the environment. Furthermore, some definitions related to green leadership still needs to be explored more broadly (Tan et al., 2011). Boiral, Baron \& Gunnlaugson (2014); Chen, et al., (2014) explained the notion of green leadership through environmental leadership as a person's ability to influence and mobilize organizational members to carry out proenvironmental activities.

Meanwhile Mittal \& Dhar (2016) described green leadership more narrowly as transformational green leadership oriented to the charismatic leadership of an individual in influencing other individuals to carry out proenvironment activities. Lee et al. (2014); Crossman (2011) explain that green leadership is also related to decision making that is oriented towards environmental values. Based on this understanding, we can define green leadership as the ability of a leader to determine pro-environmental policies and should be able to influence organizations to support proenvironmental policies.

\subsection{Environmental Policy Support}

In the last few decades, researchers have used various terms to describe actions that include behaviors similar to those of pro-environmental behavior (Larson, Stedman, Cooper, \& Decker, 2015). One of them is eco-friendly behavior, which is a kind of behavior that harms the environment as little as possible but provides great benefits for the environment (Steg \& Vlek, 2009). Eco-friendly behavior is a sort of consumer behavior under which every consumption action applies the concept of environmentally friendly. In addition to grouping eco-friendly behavior through six aspects of Padilla, Hogan \& Kaiser (2007), there are also grouping through four aspects by Larson (Larson, Stedman, Cooper, \& Decker, 2015), namely: (1) Social environmentalism, implemented through efforts to socialize or educate others about environmental issues, (2) land management, (3) lifestyles that support conservation, for example recycling, saving water and energy, minimizing waste generation and using eco-friendly goods, (4) Citizens who care about the environment, which is related to behavior which aims to participate in the process of making policies related to the environment.

\subsection{Green Efficacy Green Self-efficacy}

Based on LMX theory, the trust of members of the organization in their leaders is considered to be important. Self-Efficacy according to Bandura (1993) is a person's belief in the ability of individuals or agencies, to organize and carry out the actions required to achieve the desired goals. Furthermore Chen et al. (2014) narrowed self-efficacy as green self-efficacy which was defined as a member's belief in the ability of self and organization to implement proenvironment programs. With high self-efficacy, it is expected that individuals have confidence that the leaders as well 
as the organization can show good performance (Bandura, 1993). Green Self efficacy will be a factor that determines how individual support in achieving pro-environmental goals (Chen et. Al., 2014). Chen also added the role of self-efficacy as a mediator in the relationship between leadership and green performance.

\subsection{Green Mindfulness}

The definition of mindfulness according to Brown and Ryan (2003) is receptive attention and awareness of current conditions and experiences that occur both internally and externally. On the other hand, mindfulness is defined as the extent of attention to detail, the willingness to consider alternatives, and responsiveness to change (Langer, 1997). We can describe green mindfulness as the sensitivity, attention and awareness of organizational members to events related to the environment (Chen, et.al, 2014). Chen also believes that the existence of good green leadership can affect members' mindfulness in environmental activities and issues. The relationship between green leadership in the LMX concept with mindfulness can be seen from how leaders who have the trust of members can influence members in increasing attention to environmental issues.

\subsection{Organizational Identity}

Organizational identity as proposed by Whetten (2006) is defined as the distinctive characteristics or characteristics possessed by the organization. The concept of organizational identity consists of several components, namely: 1) ideational, 2) definitional, and 3) phenomenological. Whetten (2006) explains the existence of organizational identity which will affect organizational members in their activities as well as their performance. With regard to environmental issues, Song's research (2018) explains that there is a very close relationship between corporate strategy and employee creativity, which is mediated by organizational identity. Khalil Nezhad and Aslani (2018) explains the positive relationship between organizational identities with people's behavior. Meanwhile, Mesmer-Magnus (2018) found a strong influence of organizational identity on the performance of employees through certain groups.

\subsection{Environmental Responsibility}

Environmental responsibility basically explains about individual responsibility with his environment. Environmental responsibility is an important factor related to the value of an organization (Simpson et.al, 2008). The existence of environmental responsibility has a very close relationship with pro-environmental activities explained by Genc \& Akilli (2016) in the framework of the environmental literacy model.
Based on this opinion environmental responsibility has a role in increasing pro-environmental activities carried out by individuals.

\subsection{Hypotesis}

The relationship between green leadership, green mindfulness and green self-efficacy is related to the LMX theory which is used as a theoretical background in this study. The existence of organizational identity is a confirmation of the social identity theory used in this study. The two theoretical relationships will be tested in the same model to see how far is the influence of green leadership and organizational identity in influencing the perceptions of lectures and staff on pro-environmental policies. According to the research problem and literature review, the hypotesis in this research is:

H1: Green leadership is significantly and positively related to green mindfulness

H2: Green Leadership is significantly and positively related to green Self-Efficacy

H3: Green Self Efficacy is significantly and positively related to Environmental policies support

H4: Green mindfulness is significantly and positively related to Environmental policies support

H5: Green Leadership is significantly and positively related to Environmental policies support

H6: Responsibility is significantly and positively related to environmental policies support

H7: Organization identity is significantly moderating the relationship between green leadership toward green mindfulness

H8: Organization identity is significantly moderating the relationship between green leadership toward green selfefficacy

\section{Research Method}

This research was conducted with a quantitative approach. The quantitative analysis used a factor analysis design based on Structural Equation Modeling (SEM). Respondents in this study were obtained from the population of unit heads from teacher training institutions, lecturers and educational staff in Universitas Negeri Semarang, Central Java, Indonesia. The number of Population sample was 1,456 with 312 respondents. The data collection method used was questionnaire method which used a seven-scale Agree interval scale (1-7).

\section{Results and Discussion}

This research further reviewed the LMX Model while confirming the social identity of leadership in one model. 
The aim was to find out the influence of green leadership in increasing support for pro-environmental policy at the university. Data analysis using WarpPLS 5.0 was conducted on 312 lecturer and staff respondents at several universities in Central Java, Indonesia. Testing the quality of the models in this study can be seen in the following table:

The overall model test results in Table 1 showed that the model built in this study was in accordance with the planned conceptual model. Furthermore, testing the relationship between variables in the model can be done. The relationship between variables in this study can be seen in Figure 1.

Based on the results of this analysis we can know that GL affects GM and GSE significantly. If the effect of GL on GM was 0.13 percent with a significance level $<0.01$, then the effect of GL on the GSE was 0.62 with a probability value $<0.01$. This result mean that the $\mathrm{H} 1$ and $\mathrm{H} 2$ is accepted. The magnitude of the coefficient of determination for each variable was 13 percent and 50 percent. This showed the influence of GL on the GSE was more dominant than the green mindfulness. In this regard, research conducted by Chen, et.al (2014), also explained the influence of green transformational leadership on green mindfulness and green self-efficacy. This result also explained the LMX model theory which stated the strong role of leadership in influencing the beliefs and openness of the thought of its members (Boiral, et.al, 2014; Chen, et.al, 2014; Mittal \& Dhar, 2015).

Table 1: Model Quality Testing of WarpPLS5

\begin{tabular}{|l|c|c|}
\hline Model Fit and Quality Indices & Index & Information \\
\hline Average path coefficient (APC) & 0.283, P<0.001 & Accepted \\
\hline Average R-Squared (ARS) & 0.399, P<0.001 & Accepted \\
\hline Average Adjusted R-Squared & 0.385, P<0.001 & Accepted \\
\hline Average Block Variance Inflation Factor (AVIF) & 1.908 & Accepted \\
\hline Average Full Collonearity VIF (AFVIF) & 2.919 & Accepted \\
\hline Tenenhaus GoF (GoF) & 0.477 & Accepted \\
\hline Sympson's Paradox ratio (SPR) & 0.875 & Accepted \\
\hline R-Squared Contribution ratio (RSCR & 0.813 & 1.000 \\
\hline Statistical Suppression Ratio (SSR) & 0.813 & Accepted \\
\hline Nonlinear Bivariate Causality Direction Ratio (NLBCDR) & Accepted \\
\hline
\end{tabular}

Source: Data Processed, 2020.

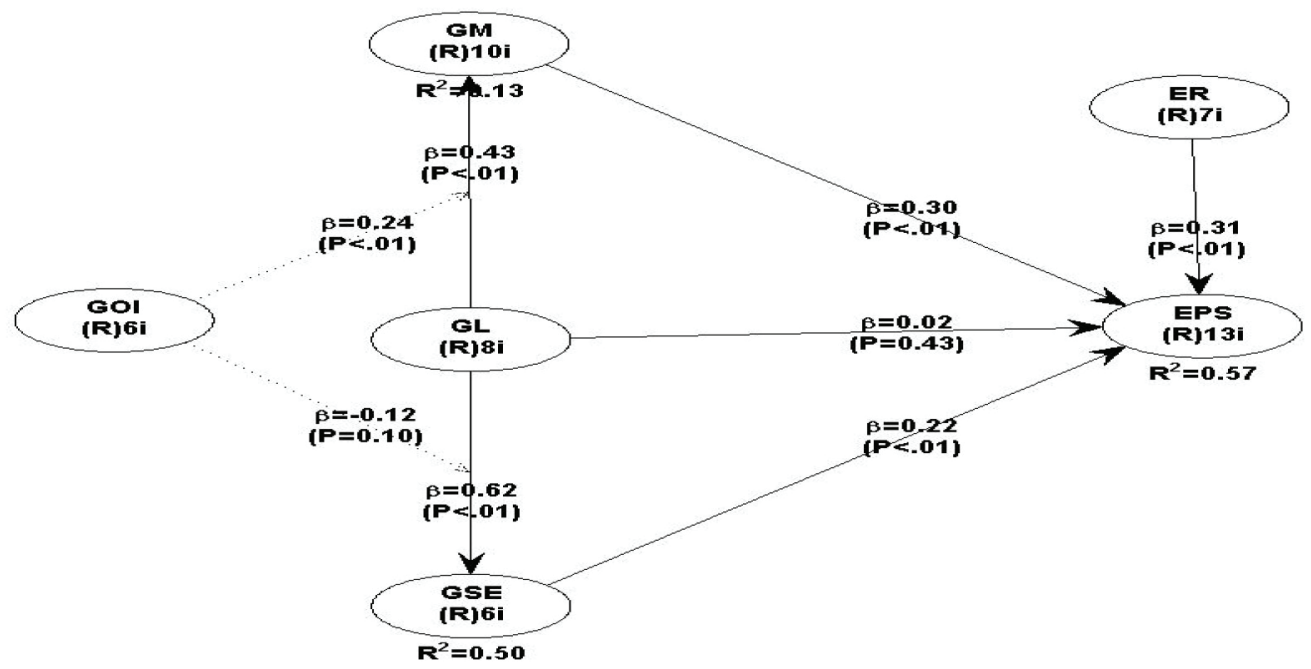

Figure 1: Analysis of Research Data Using WarpPLS 5.0 
The relationship between GSE and GL and EPS had a mediating effect. There was a positive and significant influence of green mindfulness and green self-efficacy on environmental policy support with the magnitude of the influence coefficient of 0.30 and 0.22 with a significance level $<0.01$. It mean that the $\mathrm{H} 3$ and $\mathrm{H} 4$ is accepted. These results confirmed the findings of Chen, et.al, (2014) with the same results. The relationship between GM and EPS in this study was in accordance with the opinions of Brown and Ryan (2003) and Langer (1997) which defined mindfulness as further openness of thought to problems and changes. Meyer (2011) findings explained the mediating effect of self-efficacy on employee performance. Next Jeon (2018) described the behavior of citizens who were influenced by self-efficacy.

Furthermore, no significant effect had been found on the green leadership variable directly on environmental policy support. The magnitude of the effect of GL on EPS was only 0.02 with a significance of 0.43 . The result about the relationship between Green Leadership and Eco Friendly Policy in Universities show that the H5 is rejected. These results indicated that there were differences in the findings of previous studies from Chen, et.al (2014) which explained the influence of transformational leadership on environmental performance. The existence of these findings needed to be investigated more deeply as well as a limitation of research that needed to be discussed by the next researchers.

The effect of ER on the GSE was shown by the significance $<0.01$ with a beta coefficient of 0.31 . This placed an important role on environmental responsibility in supporting pro-environmental policies at the university. It indicates that the H6 is accepted. The magnitude of the influence of GM, GL, ER and GSE on EPS as a whole was 0.57 , which indicated a deterrence of 57 percent of these variables towards supporting environmental policies at the university. Furthermore, this study also reviewed the moderating role of the green organizational identity to the LMX model which analyzed the support of lecturers and employees of University for Pro-environment policies.

The moderation test results showed that GOI moderates GL against GM with a significance of $<0.01$ and a coefficient of 0.24 , in this research $\mathrm{H} 7$ is accepted. The moderating effect of GOI on GL on GSE was not significant at the 5 percent level with a $\mathrm{P}$ value of 0.1 and a coefficient of 0.12 . It means that $\mathrm{H} 8$ is rejected. These results indicate the role of the GOI to magnify the effect of GL on GM. In the Social Identity theory of leadership, the existence of external factors outside the relationship between leadership and members also influenced the behavior of members (Francioli, et.al, 2018). Whetten (2006), Song (2018), Mesmer-Magnus (2018) explained that organizational identity affects the performance of members in the organization.

A good relationship between leaders and subordinates can be shown from the existence of feelings of mutual trust, liking, respect and feelings of mutual need (Liden, Sparrowe \& Wayne, 1997). LMX theory as explained by Graen and Uhl-Bien (1995) explains the behavior of members who are more receptive to information, influence the direction of their leaders compared to information and influence from outsiders. High-quality relationships between leaders and members are associated with several positive work-related outcomes, namely, job satisfaction and organizational commitment (Martin et al, 2016). This means that the members' support for pro-environmental policies is determined by the leadership relationship with the members based on the members' trust in their leaders.

Contrary to this in the social identity of leadership theory, the behavior of members is not solely determined by the relationship of members with their leaders, but also comes from external factors, namely the dominant group (Rast, Gaffney, Hogg \& Crisp, 2012). Rast, Gaffney, Hogg \& Crisp (2012) explained that in LMX model there is no possibility of a good relationship between leaders and members of the organization due to the presence of a dominant group that determines the perceptions of the leaders. In this regard it can be assumed that the pro-environmental policies made by the leadership are not necessarily supported by members of the organization. Based on Tran and Do (2020), social recognition affects the work motivation of lecturers, this shows that recognition of green behavior will increase the green performance of lecturers.

Green leadership can have an impact on relationships between individuals and organizations in an effort to achieve sustainable goals in the environment. Furthermore, some definitions related to green leadership still needs to be explored more broadly (Tan et al., 2011). Boiral, Baron \& Gunnlaugson (2014); Chen, et al., (2014) explain the notion of green leadership through environmental leadership as a person's ability to influence and mobilize organizational members to carry out pro-environmental activities. Lee et al. (2014); Crossman (2011) explains that green leadership is also related to decision making that is oriented towards environmental values.

Based on LMX theory, the trust of members of the organization in their leaders is considered to be important. Nguyen (2020) found that the Leader member quality had impact on job performance of organization member. Selfefficacy according to Bandura (1993) is a person's belief in the ability of individuals or agencies, to organize and carry out the actions required to achieve the desired goals. Furthermore Chen et al. (2014) narrowed self-efficacy as green self-efficacy which was defined as a member's belief in the ability of self and organization to implement proenvironment programs. With high self-efficacy, it is expected that individuals have confidence that the leaders as well as the organization can show good performance (Bandura, 1993). Green Self efficacy will be a factor that determines how 
individual support can play an important role in achieving pro-environmental goals (Chen, et.al, 2014).

Mindfulness is the extent of attention to detail, the willingness to consider alternatives, and responsiveness to change (Langer, 1997). We can describe green mindfulness as the sensitivity, attention and awareness of organizational members to events related to the environment (Chen, et.al, 2014). Chen also believes that the existence of good green leadership can affect members' mindfulness in environmental activities and issues. On the other hand, Whetten (2006) explains that the existence of organizational identity will affect organizational members in their activities as well as their performance. With regard to environmental issues, Song's research (2018) explains that there is a very close relationship between corporate strategy and employee creativity, which is mediated by organizational identity.

Khalil \& Aslani (2018) explains the positive relationship between organizational identities with people's behavior. Meanwhile, Mesmer-Magnus (2018) found a strong influence of organizational identity on the performance of employees through certain groups. On the other hand, environmental responsibility emphasizes the relationship between individuals and environmental activities (Lee, et.al, 2014). The existence of environmental responsibility has a very close relationship with pro-environmental activities as explained by Genc \& Akilli (2016) in the framework of the environmental literacy model.

\section{Conclusion}

The results of this study supported the application of the LMX model in analyzing the role of green leadership in influencing the behavior of members with regard to support for pro-environmental policies at universities. Furthermore, the existence of a green leader at the university also influences the mindfulness of lecturers and employees towards the implementation of pro-environmental policies at the university.

This study also investigated the relationship between green self-efficacy, environmental responsibility and green mindfulness of lecturers and staff at universities on their support for pro-environmental policies. Both of them were the dominant variables that influenced employee support for environmental policies support at universities. This result was in line with various previous research findings related to the effect of self-efficacy and mindfulness on organizational behavior.

In the next stage, this study analyzed the moderating effect of green organizational identity as an affirmation of the social identity theory of leadership that described the relationship between organizational identities in organizational behavior. This research put organizational identity as a moderating variable that was able to increase the role of leadership in influencing the self-efficacy and mindfulness of lecturers and employees towards pro-environmental policies. In the next research it is hoped that the explanation of green leadership indicators will not only focus on pro-environmental policy outputs. In the next research, green leadership indicators can be reviewed in terms of leadership behavior and leadership style in influencing organizational members.

\section{References}

Ali, W. (2019). Green Leadership as an Emerging Style for Addressing Climate Change Issues in Schools. Journal of Social Sciences 15, 58-68 DOI: 10.3844/jssp.2019.58.68

Al-Zawahreh, A., Khasawneh, S., \& Al-Jaradat, M. (2019). Green management practices in higher education: The status of sustainable leadership. Tert Educ Manag, 25, 53-63. https://doi. org/10.1007/s11233-018-09014-9

Arias, Á., \& Lucendo, A. J. (2019). Molecular basis and cellular mechanisms of eosinophilic esophagitis for the clinical practice. Expert Review of Gastroenterology \& Hepatology, 13(2), 99-117.

Bandura, A. (1993). Perceived self-efficacy in cognitive development and functioning. Educational Psychologist, 28(2), 117-148.

Boca, G. D., \& Saracli, S. (2019). Environmental education and student's perception, for sustainability. Sustainability, 11(6), 1553.

Boiral, O., Baron, C., \& Gunnlaugson, O. (2014). Environmental leadership and consciousness development: A case study among Canadian SMEs. Journal of Business Ethics, 123(3), 363-383.

Boiral, O., Raineri, N., \& Talbot, D. (2018). Managers' citizenship behaviors for the environment: A developmental perspective. Journal of Business Ethics, 149(2), 395-409.

Brown, K. W., \& Ryan, R. M. (2003). The benefits of being present: mindfulness and its role in psychological well-being. Journal of Personality and Social Psychology, 84(4), 822-848. https://doi. org/10.1037/0022-3514.84.4.822

Chen, Y., Tang, G., Jin, J., Xie, Q., \& Li, J.(2014). CEO s'transformational leadership and product innovation performance: The roles of corporate entrepreneurship and technology orientation. Journal of Product Innovation Management, 31, 2-17.

Colquitt, J., Lepine, J. A., Wesson, M. J., \& Gellatly, I. R. (2011). Organizational behavior: Improving performance and commitment in the workplace (Vol. 375). New York, NY: McGraw-Hill Irwin.

Cosby, D. (2014). Sustainability program leadership for human resource development professionals: A competency model. Journal of Organizational Culture, Communications \& Conflict, 18(2), 79-86

Crossman, J. (2011). Environmental and spiritual leadership: Tracing the synergies from an organizational perspective. Journal of Business Ethics, 103, 553-565. http://doi.org/b8s4gf

Dansereau Jr, F., Graen, G., \& Haga, W. J.(1975).Avertical dyad linkage approach to leadership within formal organizations: A longitudinal 
investigation of the role making process. Organizational Behavior and Human Performance, 13(1), 46-78.

Francioli, L., Conway, P. M., Hansen, Å. M., Holten, A. L., Grynderup, M. B., Persson, R., \& Høgh, A. (2018). Quality of leadership and workplace bullying: The mediating role of social community at work in a two-year follow-up study. Journal of Business Ethics, 147(4), 889-899.

Genc, M., \& Akilli, M. (2016). Modeling the relationships between subdimensions of environmental literacy. Applied Environmental Education \& Communication, 15(1), 58-74.

Graen, G. B., \& Uhl-Bien, M. (1995). Relationship-based approach to leadership: Development of leader-member exchange (LMX) theory of leadership over 25 years: Applying a multi-level multi-domain perspective. Leadership Quarterly 6:2. 219-247. https://digitalcommons.unl.edu/ managementfacpub/57

Hamidi, H., Jufri, A. W., \& Karta, W. (2019). The effect of quality of work life on teacher job satisfaction. Erudio Journal of Educational Innovation, 6(1), 19-29.

He, M., Wang, N., Long, X., Zhang, C., Ma, C., Zhong, Q., \& Shan, J. (2019). Antimony speciation in the environment: Recent advances in understanding the biogeochemical processes and ecological effects. Journal of Environmental Sciences, 75, 1439 .

Hogg, M. A., Martin, R., Epitropaki, O., Mankad, A., Svensson, A., \& Weeden, K. (2005). Effective leadership in salient groups: Revisiting leader-member exchange theory from the perspective of the social identity theory of leadership. Personality and Social Psychology Bulletin, 31(7), 991-1004.

Jeon, J. C. (2018). The effects of organizational culture on selfefficacy and organizational citizenship behavior. Culinary Science and Hospitality Research, 24(3), 121-132.

Kim, Y.J., Kim, W. G., Choi, H. M., \& Phetvaroon, K. (2019). The effect of green human resource management on hotel employees' ecofriendly behavior and environmental performance. International Journal of Hospitality Management, 76, 83-93.

Khalil N. S., \& Aslani, A. A. (2018). The Impact of Internal Brand Management on Organizational Citizenship Behaviors in Hotel Industry: The Mediating Role of Organizational Identity and Job Engagement. Journal of Tourism And Development 6(4) ; 180-200.

Kuenzi, M., \& Schminke, M. (2009). Assembling fragments into a lens: A review, critique, and proposed research agenda for the organizational work climate literature. Journal of Management, 35(3), 634-717.

Lamm, K. W., Sapp, L., \& Lamm, A. J. (2016). Leadership Programming: Exploring a Path to Faculty Engagement in Transformational Leadership. Journal of Agricultural Education, 57(1), 106-120.

Langer, E. J. (1997). The Power of Mindful Learning. Reading, MA: Addison-Wesley, Inc.

Larson, L. R., Stedman, R. C., Cooper, C. B., \& Decker, D. J. (2015). Understanding the multi-dimensional structure of pro-environmental behavior. Journal of Environmental Psychology, 43, 112-124.

Lee, M. H., Lin, C., Lin, C. K., \& Lu, W. Y. (2014). Moderating Effect of Institutional Responsiveness on the Relationship between Green Leadership and Green Competitiveness. Social Behavior and Personality: An International Journal, 42(9), 1483-1494. doi:10.2224/sbp.2014.42.9.1483

Liden, R. C., Sparrowe, R. T., \& Wayne, S. J. (1997). Leader-member exchange theory: The past and potential for the future. Research in Personnel and Human Resources Management, 15, 47-120.

Mahrani, M. and Soewarno, N. (2018), The effect of good corporate governance mechanism and corporate social responsibility on financial performance with earnings management as mediating variable, Asian Journal of Accounting Research, 3 (1) 41-60. https://doi.org/10.1108/AJAR-06-2018-0008

Malik, S. Z., Saleem, M., \& Naeem, R. (2016). Effect of leadership styles on organizational citizenship behaviour in employees of telecom sector in Pakistan. Pakistan Economic and Social Review, 54(2), 385-406.

Martin, R., Guillaume, Y., Thomas, G., Lee, A., \& Epitropaki, O. (2016). Leader-member exchange (LMX) and performance: A meta-analytic review. Personnel Psychology, 69(1), 67-121.

Mesmer-Magnus, J. R., Asencio, R., Seely, P. W., \& DeChurch, L. A. (2018). How organizational identity affects team functioning: The identity instrumentality hypothesis. Journal of Management, 44(4), 1530-1550.

Meyer, B. W., Jain, S., \& Canfield-Davis, K. (2011). The Effect of Parenthood Education on Self-Efficacy and Parent Effectiveness in an Alternative High School Student Population. Professional Counselor, 1(1), 29-40.

Mittal, S. and Dhar, R.L. (2015), “Transformational leadership and employee creativity: Mediating role of creative self-efficacy and moderating role of knowledge sharing", Management Decision, 53 (5), 894-910. https://doi.org/10.1108/MD-072014-0464

Nguyen, T. H. (2020). Impact of Leader-Member Relationship Quality on Job Satisfaction, Innovation and Operational Performance: A Case in Vietnam. Journal of Asian Finance, Economics, and Business, 7(6), 449-456. https://doi. org/10.13106/jafeb.2020.vol7.no6.449

Nguyen, H. V., Nguyen, C. H., \& Hoang, T. T. B. (2019). Green consumption: Closing the intention-behavior gap. Sustainable Development, 27(1), 118-129.

Norton, T. A., Zacher, H., Parker, S. L., \& Ashkanasy, N. M. (2017). Bridging the gap between green behavioral intentions and employee green behavior: The role of green psychological climate. Journal of Organizational Behavior, 38(7), 996-1015.

Northouse, P. G. (2018). Leadership: Theory and practice. Thousand Oaks, CA: Sage Publications.

Ones, D. S., \& Dilchert, S. (2012). Environmental sustainability at work: A call to action. Industrial and Organizational Psychology, 5(4), 444-466. 
Padilla, A., Hogan, R., \& Kaiser, R. B. (2007). The toxic triangle: Destructive leaders, susceptible followers, and conducive environments. The Leadership Quarterly, 18(3), 176-194.

Rast III, D. E., Gaffney, A. M., Hogg, M. A., \& Crisp, R. J. (2012). Leadership under uncertainty: When leaders who are nonprototypical group members can gain support. Journal of Experimental Social Psychology, 48(3), 646-653.

Robertson, J. L., \& Barling, J. (Eds.). (2015). The psychology of green organizations. New York, NY: Oxford University Press.

Simpson, M., Taylor, N., \& Barker, K. (2004). Environmental responsibility in SMEs: Does it deliver competitive advantage?. Business Strategy and the Environment, 13(3), 156-171.

Song, W., \& Yu, H. (2018). Green innovation strategy and green innovation: The roles of green creativity and green organizational identity. Corporate Social Responsibility and Environmental Management, 25(2), 135-150.

Steg, L., \& Vlek, C. (2009). Encouraging pro-environmental behaviour: An integrative review and research agenda. Journal of Environmental Psychology, 29(3), 309-317.
Tan, Barney; Ling Pan, Shan; and Zuo, Meiyun. (2011). Attaining and Enacting Green Leadership: Insights from the Green IT Initiatives of China Mobile. In: ICIS 2011 Proceedings. https://aisel.aisnet.org/icis2011/proceedings/ eastmeetswest $/ 4$

Tran, T. T., \& Do, Q. H. (2020). Factors Affecting Job Motivation among Faculty Members: Evidence from Vietnamese Public Universities. Journal of Asian Finance, Economics and Business, 7(9), 603-611. https://doi.org/10.13106/jafeb.2020. vol7.no9.603

Tran, D. T., Lee, L. Y., Nguyen, P. T., \& Srisittiratkul, W. (2020). How Leader Characteristics and Leader Member Exchange Lead to Social Capital and Job Performance. Journal of Asian Finance, Economics, and Business, 7(1), 269-278. https://doi. org/10.13106/jafeb.2020.vol7.no1.269

Whetten, D. A. (2006). Albert and Whetten revisited: Strengthening the concept of organizational identity. Journal of Management Inquiry, 15(3), 219-234.

Yukl, G. (2015). Leadership in Organizations (9th ed.). India: Pearson Education India. 